In February, 1957, a regular summer hauling-out ground for several hundred elephant seals was discovered in the Vestfold Hills, Australian Antaretic Territory, $68^{\circ} 35^{\prime}$ S., $77^{\circ} 58^{\prime} \mathrm{E}$.

This area contains about 300 square miles of exposed rock, ice-free in summer, with beaches suitable for these seals. During the establishment of the Australian National Antarctic Research Expeditions' Station 'Davis', a number of moulting elephant seals were found in the neighbourhood. Seven were seen on February 1, 37 on February 8 and 77 on February 19. Later, Robert Dingle, commander of the station, reported counts of more than 400 on March 6, more than 250 on April 2 and 17 on April 28. These counts were made on four beaches with a total length of about $1,300 \mathrm{ft}$. One female was seen in February but all the rest wore males. Bachelor bulls were in the majority, but there were a number that could be classed as mature harem bulls; adolescents 2-4 yr. old made up 5 per cent of the total on March 6 and 25 per cent on April 2. Skulls, teoth and carcasses on the beach showed that it must have been visited regularly for a number of years. By the ond of April the last seals to leave had to cross 5 miles of fast ice to reach open water.

There is no difference in date of moulting between these seals and more northerly populations. Although nothing is yet known of the behaviour of the sea-ice at the Vestfold Hills in spring, it is extremely unlikely that the beaches are ice-free in time for the breeding season (September-November). Even if the shores were ice-free, it is unlikely that the elephant seals would penetrate the wide belt of pack-ice farther north. It is much more probable that a small part of the large population breeding at Kerguolen and Heard Island goes south in summer. Since branded elephant seals from Heard Island have twice been reported at Marion Island, a distance of 1,614 statute miles, the 1,082 miles from Heard to the Vestfold Hills is well within their powers. The situation may best be compared with that at the South Orkneys', where the breeding population is very small but tho summer population is about 10,000 , and reflects a wide dispersal of elephant soals over suitable feeding grounds.

Antarctic Division,

Department of External Affairs, Melbourne.

May 9.

"Bagshawe, T. W., "Two Men in the Antarctic" (Cambridge, 1939).

${ }^{2}$ Laws, R. M., Falkland Is. Dependency Survey, 13 (1956).

${ }^{3}$ Sapin-Jaloustre, J., Mammalia, 16, 179 (1952).

- Mawson, D., "The Home of the Blizzard" (Feinemann, London, 1915).

${ }^{5}$ Marshall, E. H., Geog. J., 75, 251 (1930).

- Austin, jun., O. L., Bird-banding, 28, 1 (1957).

7 Wilson, E. A., Brit. Nat. Antarctic Exp. 1901-4, Nat. Hist., 2, 1 $(1907)$.

\section{The Freshwater Eel Anguilla obscura Gunther, 1871, in Southern Africa}

ON August 8 fifteen eols were collected in the Mgqakwobe River $\left(27^{\circ} 22^{\prime}\right.$ E., $32^{\circ} 50^{\prime}$ S.), a tributary of the Buffalo Rivor, Capo Province. One specimen, a short-fin species $35.5 \mathrm{~cm}$. in longth and very dark in colour, differed in appearance from any of this group previously found. A subsequent detailed examination has shown this to be without doubt Anguilla obscura Gunther, 1871, a Pacific spocies not previously reported west of New Guinea and a notable discovery on the African continent.

In his revision of the genus Anguilla Shaw, Ege ${ }^{1}$ examined Gunther's type of obscura, and detailed specifications are available for identification of this species. The characteristics of this specimen from the Buffalo River system have been found to fall within the range of those given for Anguilla obscura in every detail. The following eritical evaluations were observed in the specimen now described: (a) length of intermaxillary-vomerine band of teeth, 73 per cent of the distance from the front margin of that band to the posterior end of the right maxillary band; (b) the distance between verticals through the anus and the origin of the dorsal fin, $2 \cdot 4$ por cent of the total length; (c) total number of vertebra $=103$. The gonads were not developed, and the sex could not be detormined.

Whether this specimen of Anguilla obscura in the Buffalo River system is a stray or not can only be shown by future investigations. That in its larval life and metamorphosis it may have endured a most extensive migration is of far-reaching significance.

It has boen shown that Indo-Pacific freshwater eels have several, presumably well-separated spawning areas ${ }^{2}$, all of which are close to land, though only a few have been positively located. Larvæ of Anguilla bicolor bicolor McClelland and of Anguilla nossambica Peters, have definitely been found between the northern tip of Madagascar and the African mainland ${ }^{2}$. Elvers of the former, $5 \cdot 0-6 \cdot 0 \mathrm{~cm}$. in length, have been collected near Dar-es-Salaam ${ }^{3}$, and elvers of the latter, as well as those of Anguilla marmorata Quoy and Gaimard, from the rivers of Madagascar ${ }^{1}$. In consequence, for these African eels an area east of Madagascar has been suggested as a spawning ground. In the case of Anguilla marmorata, which is dominantly western Pacific in distribution, we can expect to find other spawning areas nearer its major distribution area.

In this connexion it is probably significant that young eels of all species migrating up the Buffalo River are variable in size, ranging from 10 to $22 \mathrm{~cm}$. in length 4 , an unusual feature if they belong to a single age-group. No specimens of migrating young eels of this type from the Buffalo River that $I$ have examined are fully pigmented; on Strubberg's specification ${ }^{5}$ they are elvers in the last stages of metamorphosis, which means that they can have been in fresh water only a very short time. The range in size ean therefore not be explained by sojourn in fresh water, but more likely indicates an unusually long period, anything from 2 to 5 years, at seamuch longer than would be required for those elvers to travel from the vicinity of Madagascar to southern Africa. It may well be that a number of the elvers found migrating up the Buffalo River do not come from the same spawning ground as those reaching Madagascar, but from one possibly much more distant, which they may well share with other spocios such as marmorata and obscura.

Department of Icthyology, Rhodes Univorsity, Grahamstown.

${ }^{1}$ Dana Report No. 16 (1939)

2 Dana Report No. 22 (1942)

${ }^{3}$ Frost, W. E., Nature, 179, 594 (1957).

4 Jubb, R. A., Nature, 180, 47 (1957).

s Strubberg, A. C., Medd. Komm. Havunders., Fiskeri, 4, s. 